\title{
Effect of Organic Dye on the Photovoltaic Performance of Dye-Sensitized ZnO Solar Cell
}

\author{
Nuhad A. Al-Omair ${ }^{1}$, Safenaz M. Reda ${ }^{2 *}$, Farah M. Al-Hajri ${ }^{3}$ \\ ${ }^{1}$ Chemistry Department, College of Science for Girls, University of Dammam, Dammam, KSA \\ ${ }^{2}$ Chemistry Department, Faculty of Science, Benha University, Benha, Egypt \\ ${ }^{3}$ King Fahd University of Petroleum and Minerals School, Dhahran, KSA \\ Email: safenazr@yahoo.com
}

Received December 6, 2013; revised January 18, 2014; accepted January 30, 2014

Copyright (C) 2014 Nuhad A. Al-Omair et al. This is an open access article distributed under the Creative Commons Attribution License, which permits unrestricted use, distribution, and reproduction in any medium, provided the original work is properly cited. In accordance of the Creative Commons Attribution License all Copyrights @ 2014 are reserved for SCIRP and the owner of the intellectual property Nuhad A. Al-Omair et al. All Copyright (C) 2014 are guarded by law and by SCIRP as a guardian.

\section{ABSTRACT}

This work investigated the influence of the organic dyes Orange IV and Eosin $\mathrm{Y}$ as photosensitizers on the photovoltaic parameters of $\mathrm{ZnO}$ photoelectrode dye-sensitized solar cells (DSSCs). ZnO was prepared by homemade ZnO nanoparticles. X-ray powder diffraction (XRD), scanning electron microscopy (SEM) and BET measurements were used to characterize the structures and the morphology of $\mathrm{ZnO}$ nanostructures. The Orange IV demonstrated the best performance compared with the cell sensitized with the Eosin Y. This occurred as Orange IV demonstrated the highest molar extinction coefficient.

\section{KEYWORDS}

\section{ZnO Nanoparticles; Orange IV; Eosin Y; Dye-Sensitized Solar Cell}

\section{Introduction}

Of many problems facing mankind, those concerning the availability and distribution of energy will ultimately be most important. As fossil fuel becomes depleted, we will turn more and more to alternative sources and eventually depend on energy technologies based on nuclear fusion, nuclear fission and solar energy.

The sun's energy is the primary source for most energy forms found on the earth. Solar energy is clean, abundant and renewable. Solar energy holds tremendous potential to benefit our world by diversifying our energy supply, reducing our dependence on imported fuels, improving the quality of the air we breathe and stimulating our economy by creating jobs in the manufacture and installation of solar energy systems. Currently, a significant and growing solar industry in the world is serving customers by providing solar water heating, pool heating and solar-electric systems [1].

Among alternative forms of solar cells, dye-sensitized solar cells (DSSCs) are low-cost solar-cells belonging to the group of thin film solar cells. These cells have a lot of

\footnotetext{
*Corresponding author.
}

potentials because they can be made and manufactured with low-cost materials. Unlike traditional solar cells, dye-sensitized cells can work effectively in low light conditions and are less susceptible to losing energy to heat. It is based on a semiconductor formed between a photo-sensitized anode and an electrolyte [2].

Generally, a DSSC device comprises a large band gap semiconductor nanocrystalline porous electrode which was fabricated on a transparent conducting oxide (TCO) glass and modified with dye (usually the ruthenium (II) complex), a Pt counter electrode and an electrolyte solution (usually $\mathrm{I}_{3}{ }^{-} / \mathrm{I}^{-}$in a mixture of organic solvents) between the two electrodes $[3,4]$. The role of semiconductor (e.g., anatase $\mathrm{TiO}_{2}$ ) porous electrode is crucial, and the cell's overall energy conversion efficiency strongly depends on the surface and electronic properties of the electrode [4,5]. Until now, the DSSCs made with porous anatase $\mathrm{TiO}_{2}$ films have represented the highest energy conversion efficiency of $11.1 \%$ [6], although various oxide semiconductors, such as $\mathrm{ZnO}$ [7], have been used to prepare the porous electrode. The $\mathrm{ZnO}$ can be used as electrode material for the DSSCs due to its band gap 
(3.37 eV) and electronic properties similar to $\mathrm{TiO}_{2}$. In addition, $\mathrm{ZnO}$ with flat band potential higher than $\mathrm{TiO}_{2}$ is beneficial for enhancing the cell's open-circuit photovoltage.

Many kinds of dyes such as Eosin Y and Orange IV have been used as sensitizers. Organic dyes have many advantages for their application in DSSCs. Firstly, absorption coefficients of organic dyes are generally much higher than that of metal complexes, therefore, the used amount of organic dyes is relatively lower. Secondly, there are many species of organic dyes, and light absorption band can be easily controlled and turned. Thirdly, the organic dyes on semiconductor film are easily removed by sinter in air; therefore, recycle use of the photo electrode leads to great cost-down.

In this paper, we present our study on the synthesis and characterization of $\mathrm{ZnO}$ in nanocrystalline form to prepare the photoelectrochemical solar cell. There are few studies on the sensitization of the $\mathrm{ZnO}$ electrode by organic dyes. This paper focuses on the sensitization of this metal oxide with Eosin Y dye and Orange IV dyes.

\section{Experimental}

\subsection{Preparation of $\mathrm{ZnO}$ Nanoparticles}

Zinc nitrate hexahydrate $\left(\mathrm{Zn}\left(\mathrm{NO}_{3}\right)_{2} \cdot 6 \mathrm{H}_{2} \mathrm{O}\right)$, ammonium hydrogen carbonate $\left(\mathrm{NH}_{4} \mathrm{HCO}_{3}\right)$, polyethylene glycol 400 (PEG 400) and, ethanol were obtained from commercial sources as analytical reagents and used without further purification. Typical preparation process as follows: $23.80 \mathrm{~g} \mathrm{Zn}\left(\mathrm{NO}_{3}\right)_{2} \cdot 6 \mathrm{H}_{2} \mathrm{O}$ were dissolved into 200 $\mathrm{ml}$ anhydrous ethanol, $2.0 \mathrm{~g}$ PEG 400 were added slowly into the obtained solution under magnetic stirring. Then, $15.80 \mathrm{~g} \mathrm{NH}_{4} \mathrm{HCO}_{3}$ were dissolved into $140 \mathrm{ml}$ distilled water and $200 \mathrm{ml}$ ethanol. The above $\mathrm{Zn}\left(\mathrm{NO}_{3}\right)_{2}$ solution was added dropwise into the $\mathrm{NH}_{4} \mathrm{HCO}_{3}$ solution under stirring. The resulting white was filtrated and washed with $1.0 \mathrm{M} \mathrm{NH}_{4} \mathrm{HCO}_{3}$ solution and ethanol several times, and dried at $80^{\circ} \mathrm{C}$ for $6 \mathrm{~h}$ to produce white precursor. The dried precursor was further calcined at $400^{\circ} \mathrm{C}$ for $2 \mathrm{~h}$ to obtain $\mathrm{ZnO}$ nanoparticles [2].

\subsection{Photoelectrode Preparation}

The procedure for fabricating a ZnO-coated working electrode of a DSSC (Figure 1) is as follow: $2 \mathrm{~g}$ of $\mathrm{ZnO}$ was ground in a mortar with of $2 \mathrm{ml}$ of water, $8 \mathrm{ml}$ ethanol, $0.2 \mathrm{ml}$ of acetylacetone and $0.1 \mathrm{ml}$ Triton X-100. The resulting paste was spread on the top of a FTO-glass substrate (transmission $>70 \%$ in visible and sheet resistance $20 \Omega$ /square). After air drying, the film electrode was fired for $30 \mathrm{~min}$. at $200^{\circ} \mathrm{C}$. The resulting film thickness was about $20 \mu \mathrm{m}$. The dye-sensitized electrodes were prepared by immersing the films in Orange IV

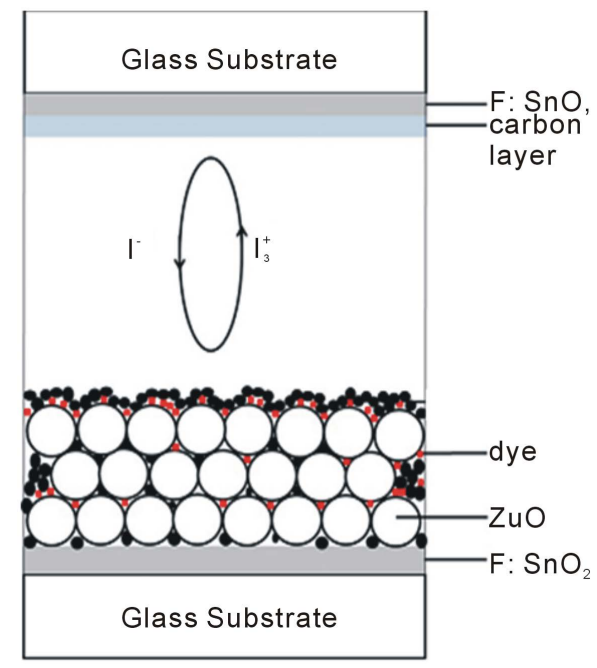

Figure 1. Schematic of the DSSC with a ZnO-coated electrode.

(sigma) and Eosin Y (sigma) ethanol solution (0.1 mM) overnight at room temperature.

\subsection{Assembling the DSSCs}

The dye-sensitized electrode was assembled in a typical sandwich-type cell; namely, the identical carbon FTO counter electrode was placed over the dye-sensitized electrode, and then the electrolyte solution, containing $0.5 \mathrm{M} \mathrm{KI}$, and $0.05 \mathrm{M} \mathrm{I}_{2}$ in acetonitrile, was sandwiched between the photoanode and the counter electrode by firm press and the edges of the cell were sealed. The area of the cell was $2 \mathrm{~cm}^{2}\left(1 \times 2 \mathrm{~cm}^{2}\right)$.

Direct sun light was used to illuminate the DSSC. A digital source-meter (Keithley 2400) was used to measure the open-circuit photovoltage and the short-circuit photocurrent of the DSSC. In addition, the power conversion efficiency $\eta$ of the DSSC is given by [8]:

$$
\eta=\frac{I_{s c} V_{o c} F F}{P_{\text {in }}}
$$

In Equation (1), $V_{o c}, I_{s c}$, and $P_{\text {in }}$ represent the opencircuit photo voltage, the short-circuit photocurrent per unit area, and the incident light power $\left(1000 \mathrm{~mW} / \mathrm{cm}^{2}\right)$, respectively. Aside from this, the fill factor FF is determined by [8]:

$$
F F=\frac{V_{m} I_{m}}{V_{o c} I_{s c}}
$$

In Equation (2), $V_{\max }$ and $I_{\max }$ represent the voltage and the current per unit area at the maximum output power point, respectively.

\section{Characterization of $\mathrm{ZnO}$ Nanoparticles}

A detailed study of the fundamental characteristics of the 
$\mathrm{ZnO}$ was conducted by several techniques:

1) X-ray powder diffractometer (Diano Corporation USA diffractometer) with a monochromated Co radiation $(\lambda=0.179 \mathrm{~nm})$ was employed to assess the crystallinity of the $\mathrm{ZnO}$ at room temperature.

2) Surface morphology was investigated by SEM (Jeol JXA-840 electron probe microanalyzer).

3) The surface properties namely BET surface area was determined from $\mathrm{N}_{2}$ adsorption isotherm using conventional or classical volumetric apparatus.

4) Fourier transform infrared spectra are generated by the absorption of electromagnetic radiation in the frequency range 400 to $4000 \mathrm{~cm}^{-1}$. Different functional groups and structural features in the molecule absorb at characteristic frequencies. The frequency and intensity of absorption are the indication of the band structures and structural geometry of the molecule. FTIR spectra were taken using Thermo Avtar 370 spectrometer.

\section{Results and Discussion}

\subsection{Characterization of $\mathrm{ZnO}$ Nanoparticles}

XRD patterns of the $\mathrm{ZnO}$ are shown in Figure 2. The diffraction peaks from the $\mathrm{ZnO}$ at $2 \theta=\left(31.9^{\circ}\right),\left(34.6^{\circ}\right)$, $\left(36.4^{\circ}\right),\left(51.7^{\circ}\right),\left(56.7^{\circ}\right),\left(62.9^{\circ}\right)$, and $\left(68.1^{\circ}\right)$ to the $\left(\begin{array}{ll}1 & 0\end{array}\right)$, (0 0 2), (l $\left.\begin{array}{lll}0 & 1\end{array}\right),\left(\begin{array}{lll}1 & 0 & 2\end{array}\right),\left(\begin{array}{lll}1 & 0 & 3\end{array}\right),\left(\begin{array}{lll}1 & 1 & 2\end{array}\right)$ and (2 0 1) diffraction planes, respectively. These diffraction planes can be indexed to the Zincite structure of ZnO (DB card, No. 01-074-9940), indicating its high crystallinity [2].

The average crystallite size of the prepared $\mathrm{ZnO}$ was calculated using the Scherrer equation [9]. The determined average size of the prepared $\mathrm{ZnO}$ was found to be 40 nm.

Figure 3 shows the SEM images of the $\mathrm{ZnO}$ nanopowder indicating the surface morphology. As can be seen from Figure 3(a), the as-synthesized sample has a relative uniform particle diameter. The inserted selected area in Figure 3(a) indicates that the high crystallinity of $\mathrm{ZnO}$, which is beneficial for the improvement of photoelectrochemical properties of its corresponding film electrode. Figure 3(b) shows the existence of some aggregates of ZnO. These aggregates were found to vary in size. The presence of the aggregates can affect the properties and performance of the resulting solar cells. The formation of aggregates of nanoparticles was enhanced by aging the $\mathrm{ZnO}$ paste for certain time intervals before use [2].

Figure 4 shows the FT-IR absorption spectrum of $\mathrm{ZnO}$ nanoparticles. The peak at $472.54 \mathrm{~cm}^{-1}$ is the characteristic absorption of $\mathrm{Zn}-\mathrm{O}$ bond.

The Analyzing the hysteresis loop shapes of nitrogen isotherms based on adsorption-desorption isotherms was studied. The as-prepared $\mathrm{ZnO}$ show a type-II adsorp-

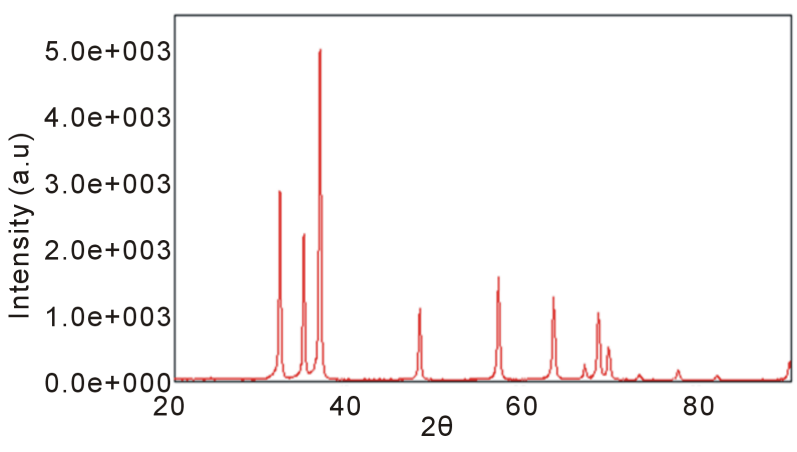

Figure 2. X-ray diffraction patterns of $\mathrm{ZnO}$ powder.

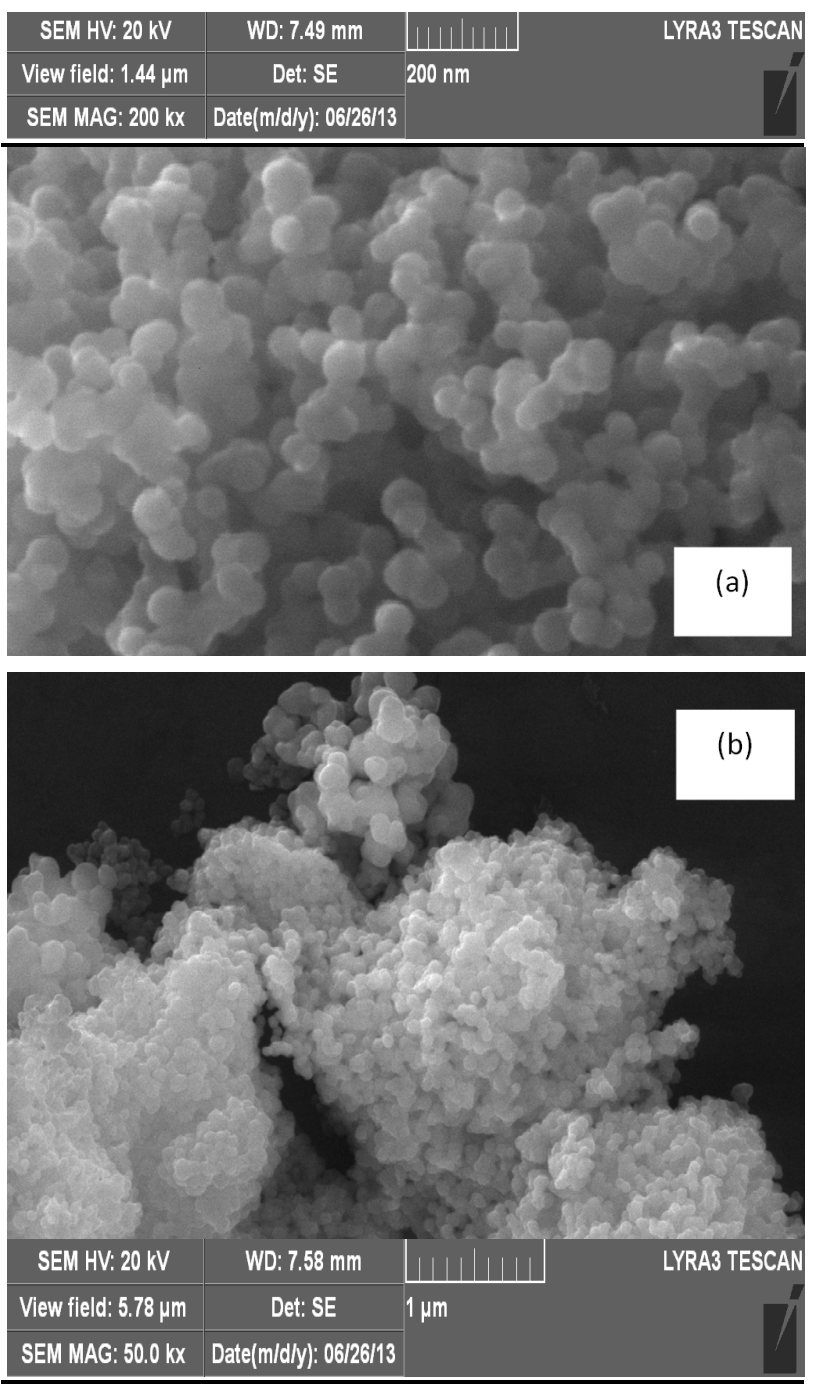

Figure 3. SEM images of the prepared $\mathrm{ZnO}$ powder.

tion-desorption isotherm, confirming that the sample is mesoporous [10]. The surface area and the average pore radius were calculated as method reported elsewhere [11]. The surface area is $2.96 \mathrm{~m}^{2} / \mathrm{gm}$ and the average pore radius of about $2 \mathrm{~nm}$. Moreover, the hysteresis loop would suggest that the shape of pore is a wide-mouth pore 


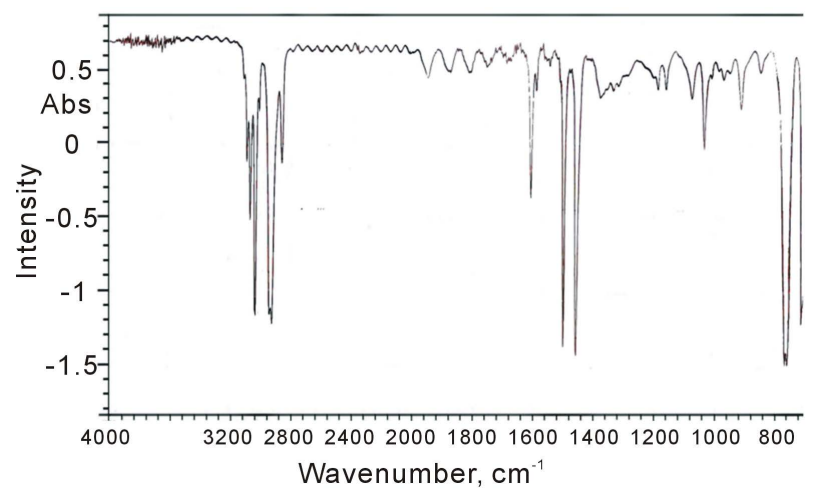

Figure 4. FTIR spectra of $\mathrm{ZnO}$ powder.

shape. This type of porous photoelectrode surface permits a better wetting of the film by the adsorbed dye.

Thus, the obtained results show that the prepared $\mathrm{ZnO}$ powder demonstrates a great potential for use as electrode material in dye-sensitized solar cell.

\subsection{Voc, Isc, $\eta$, and I-V Curve of DSSC}

Figure 5 shows the I-V curves of the DSSCs with various types of organic dyes under illumination. It was found that the cell sensitized with Orange IV dye showed the largest area of the current-density curve, indicating that this cell generated the highest output power. Meanwhile, the cell utilizing the Eosin Y dye showed the smallest area of the current-density curve, generating the lowest power. However, it was noticeable that the I-V curve areas of the cells were not much different, leading to small differences in the photovoltaic parameters presented in Table 1. From the table, it can be seen that the DSSC with Orange IV dye performed with the highest $I_{s c}$, $V_{o c}$ and $\eta$. Meanwhile, the device sensitized with the Eo$\sin \mathrm{Y}$ demonstrated the lowest $I_{s c}, V_{o c}$ and $\eta$. This leads to more electrons being injected from Orange IV dye molecules to the conduction band of $\mathrm{ZnO}$ upon light illumination, resulting in an enhancement of the photovoltaic parameters of the cell such as $I_{s c}$ and $\eta$. Moreover, the molar extinction coefficient of Orange IV was measured to be over $11.12 \times 10^{4} \mathrm{l} \cdot \mathrm{mole}^{-1} \cdot \mathrm{cm}^{-1}$, while the molar extinction coefficient of Eosin $\mathrm{Y}$ was approximately $3.12 \times 10^{4} \mathrm{l} \cdot \mathrm{mole}^{-1} \cdot \mathrm{cm}^{-1}$. Due to the higher extinction coefficient of Orange IV, fewer dye molecules need to be adsorbed on the semiconductor surface in order to achieve high efficiency results. As a result, the maximum efficiency of cells sensitized with Orange IV can be achieved for a lower film width than for cells sensitized with Eosin Y.

\section{Conclusion}

A $\mathrm{ZnO}$ nanoparicle was prepared, and it was then applied as working electrode in a solar cell sensitized with

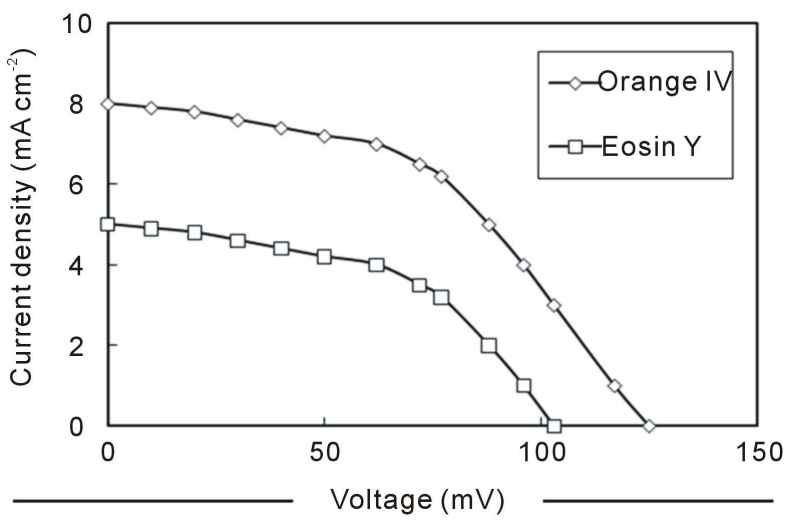

Figure 5. Photocurrent-voltage characteristics of dye sensitized solar cell device based on $\mathrm{ZnO}$ electrode.

Table 1. Photovoltaic parameters of Orange IV and Eosin Y dye-sensitized nanocrystalline $\mathrm{ZnO}$ solar cells.

\begin{tabular}{ccccccc}
\hline Samples & $\begin{array}{c}I_{s c} \\
\left(\mathrm{~mA} \cdot \mathrm{cm}^{-2}\right)\end{array}$ & $\begin{array}{c}V_{o c} \\
(\mathrm{mV})\end{array}$ & $\begin{array}{c}I_{m} \\
\left(\mathrm{~mA} . \mathrm{cm}^{-2}\right)\end{array}$ & $\begin{array}{c}V_{m} \\
(\mathrm{mV})\end{array}$ & $\mathrm{FF}$ & $\eta \times 10^{-2} \%$ \\
\hline Orange IV & 8 & 125 & 6.5 & 72 & 0.46 & 0.46 \\
Eosin Y & 5 & 103 & 3.5 & 72 & 0.48 & 0.19 \\
\hline
\end{tabular}

$I_{s c}$ : Short circuit current; $V_{o c}$ : Open circuit voltage; $I_{m}$ : Maximum current; $V_{m}$ : Maximum voltage; FF: Fill factor; $\eta$ : overall energy conversion yield.

Orange IV and Eosin Y dyes. The cells sensitized with Orange IV dye demonstrated the best photovoltaic performance compared with the cell sensitized with Eosin dye. The cell sensitized with Orange IV showed the highest short-circuit density, $I_{s c}$, of $8 \mathrm{~mA} \cdot \mathrm{cm}^{-2}$ and conversion efficiency of $0.46 \%$.

\section{Acknowledgements}

The authors wish to Research Units in Science College at University of Dammam for their support and cooperation through this work.

\section{REFERENCES}

[1] J. Nelson, “The Physics of Solar Cells,” Imperial College Press, London, 2003. http://dx.doi.org/10.1142/p276

[2] L. Lu, R. Li, K. Fan and T. Peng, "Effects of Annealing Conditions on the Photoelectrochemical Properties of Dye-Sensitized Solar Cells Made with ZnO Nanoparticles,” Solar Energy, Vol. 84, No. 5, 2010, pp. 844-853. http://dx.doi.org/10.1016/j.solener.2010.02.010

[3] V. Kandavelu, H. S. Huang, J. L. Jian, T. C. K. Yang, K. L. Wang and S. T. Huang, "Novel Iminocoumarin Dyes as Photosensitizers for Dye-Sensitized Solar Cell," Solar Energy, Vol. 83, No. 4, 2009, pp. 574-581. http://dx.doi.org/10.1016/j.solener.2008.10.002

[4] M. Gratzel, "Dye-Sensitized Solar Cells," Journal of Photochemistry and Photobiology C, Vol. 4, No. 2, 2003, pp. 145-153.

http://dx.doi.org/10.1016/S1389-5567(03)00026-1 
[5] L. Yang, Z. X. Zhang, S. H. Fang, X. H. Gao and M. Obata, "Influence of the Preparation Conditions of $\mathrm{TiO}_{2}$ Electrodes on the Performance of Solid-State Dye-Sensitized Solar Cells with CuI as a Hole Collector," Solar Energy, Vol. 81, No. 6, 2007, pp. 717-722. http://dx.doi.org/10.1016/j.solener.2006.10.001

[6] Y. Chiba, A. Islam, Y. Watanabe, R. Komiya, N. Koide and L. Y. Han, "Dye-Sensitized Solar Cells with Conversion Efficiency of 11.1\%," Journal of Applied Physics Part 2, Vol. 45, 2006, pp. 638-640.

[7] T. P. Chou, Q. F. Zhang, G. E. Fryxell and G. Z. Cao, "Hierarchically Structured ZnO Film for Dye-Sensitized Solar Cells with Enhanced Energy Conversion Efficiency,” Advanced Materials, Vol. 19, No. 18, 2007, pp. 25642588. http://dx.doi.org/10.1002/adma.200602927
[8] C. S. Chou, F. C. Chou and J. Y. Kang, "Preparation of ZnO-Coated $\mathrm{TiO}_{2}$ Electrodes Using Dip Coating and Their Applications in Dye-Sensitized Solar Cells," Powder Technology, Vol. 215-216, 2012, pp. 38-45. http://dx.doi.org/10.1016/j.powtec.2011.09.003

[9] M. Ristic, M. Ivanda, S. Popvić and S. Musić, "Dependence of Nanocrystalline $\mathrm{SnO}_{2}$ Particle Size on Synthesis Route,” Journal of Non-Crystalline Solids, Vol. 303, No. 2, 2002, pp. 270-280. http://dx.doi.org/10.1016/S0022-3093(02)00944-4

[10] J. H. de Boer, "The Structure and Properties of Porous Materials,” Butterworths, London, 1958.

[11] S. J. Gregg and K. S. W. Sing, "The Adsorption, Surface Area and Porosity,” Academic Press, London, 1967. 